\title{
Multi-tool diagnosis of an outbreak of ranavirosis in amphibian tadpoles in the Canadian boreal forest
}

\author{
M. J. Forzán ${ }^{1, *}$, J. Bienentreu' ${ }^{2}$, D. M. Schock ${ }^{2,3}$, D. Lesbarrères ${ }^{2}$ \\ ${ }^{1}$ Cornell Wildlife Health Lab, Department of Population Medicine, Animal Health Diagnostic Center, \\ Cornell University College of Veterinary Medicine, Ithaca, NY 14853, USA \\ ${ }^{2}$ Department of Biology, Laurentian University, Sudbury, ON, Canada, P3E 2C6 \\ ${ }^{3}$ University Studies and Environmental Technology, Keyano College, Fort McMurray, AB, Canada, T9H $2 \mathrm{H7}$
}

\begin{abstract}
Investigation of mortalities in isolated wild amphibian populations presents diagnostic difficulties that can hinder reaching a definitive diagnosis for the cause of death. Disease can only be diagnosed when pathogen presence (e.g. detection by PCR) is linked to tissue lesions (histopathology) in the host. We report a 2-site outbreak of ranavirosis in wild anuran tadpoles in the boreal forest of Wood Buffalo National Park, Canada, diagnosed by histologic and molecular techniques. Mortalities occurred in wood frog Rana sylvatica tadpoles and boreal chorus frog Pseudacris maculata tadpoles. Lack of mortality in sympatric Canadian toad Bufo (Anaxyrus) hemiophrys tadpoles suggested lower disease susceptibility in this species. In the former 2 species, ranavirosis was diagnosed based on consistent histopathology, immunohistochemistry (IHC), in situ hybridization (ISH), and quantitative PCR results. The most common histopathologic lesion present in wood and boreal chorus frog tadpoles was necrosis of the skin, oral mucosa, renal tubular epithelium, renal hematopoietic tissue, and branchial epithelium. Mild hepatic and pancreatic necrosis and rare intracytoplasmic inclusion bodies in hepatocytes were less common. Skeletal and connective tissues in budding limbs often had multifocal to coalescing necrosis and were intensely positive for ranavirus, with IHC staining even in areas where no obvious necrosis could be observed. Abundant IHC and ISH staining in actively growing tissues support a link between disease emergence and amphibian developmental stage. Our findings provide a definitive diagnosis of ranavirosis in free-living amphibians and highlight the effectiveness of multi-tool approaches to mortality investigation and elucidation of pathogenesis of ranavirosis in wild amphibians.
\end{abstract}

KEY WORDS: Ranavirus . Hylidae · Wild population · Diagnostic assays · qPCR · Immunohistochemistry $\cdot$ In situ hybridization $\cdot$ Boreal forest

\section{INTRODUCTION}

Infectious disease was proposed to play a role in the distribution and abundance of animal populations several decades ago (May 1988). The Amphibian Specialist Group (ASG) of the International Union for the Conservation of Nature has recognized

${ }^{*}$ Corresponding author: mdf93@cornell.edu infectious disease as a major threat to amphibian biodiversity since the beginning of the 21st century (Gascon et al. 2007). One of the priorities of the current ASG's Strategic Plan is active surveillance for amphibian pathogens in the wild, particularly focused on ranaviruses and chytrid fungi (Wren et al. 2015). Investigation of mortalities in wild amphibian

(C) The authors 2019. Open Access under Creative Commons by Attribution Licence. Use, distribution and reproduction are unrestricted. Authors and original publication must be credited. 
populations, however, presents some diagnostic difficulties, particularly if they occur in isolated areas. Detection of mortality events, collection of samples and preservation of specimens are logistically difficult. Cause of death determination is often hindered by limited or absent suitable specimens for examination. Molecular techniques, such as PCR, allow for detection of a pathogen's nucleic acid and serve as supporting evidence of its presence in the environment or host. PCR tests alone, however, cannot determine cause of death because presence of a pathogen does not equal disease (e.g. Kriger et al. 2007). Pathogen detection must be associated with lesions in the host in order to be considered as the cause of disease or, in some cases, death (Maxie 2016). Thus, identification of histological lesions along with tests that confirm the presence of a pathogen are necessary to reach a cause-of-death diagnosis.

The presence of Ranavirus sp. and one of the chytrid fungi, Batrachochytrium dendrobatidis, in wild amphibian populations in the Northwest Territories (NWT), Canada, was first reported in 2010 (Schock et al. 2010). The surveys focused on the western part of the territory, including within Nahanni National Park, and reported no confirmed mortality events due to either pathogen. Additional amphibian surveys in the southeast part of the NWT and northeast Alberta, including boreal forest within Wood Buffalo National Park, have taken place periodically since 2009 (D. Schock and J. Bienentreu unpubl.). During the 2017 survey, an outbreak of mortalities amongst tadpoles of boreal chorus frogs Pseudacris maculata and wood frogs Rana sylvatica (Lithobates sylvaticus) was observed at 2 sites. To confirm causality, we performed extensive histopathologic examinations and applied special diagnostic techniques, namely immunohistochemistry (IHC) and in situ hybridization (ISH), on all tadpoles found dead or moribund. We detail the diagnostic results, report for the first time mortality and lesions of ranavirosis in boreal chorus frogs, and validate the use of IHC and ISH as reliable techniques to detect ranaviruses in both wood frog and boreal chorus frog tadpoles.

\section{MATERIALS AND METHODS}

During amphibian surveys in northern areas of Wood Buffalo National Park in late June 2017, dead and moribund tadpoles were observed at 2 wetland locations (Fig. 1). All freshly dead tadpoles were collected for post-mortem examination. Tadpoles that appeared healthy or had only mild signs of dis- ease, i.e. lethargy or small numbers of petechial hemorrhages in the skin, were sampled (tail-clipped) and released. Dead tadpoles in obvious advanced stages of decomposition were tail-clipped and discarded in situ. From Site A $\left(60.02838^{\circ} \mathrm{N}\right.$, $113.02637^{\circ} \mathrm{W}$ ), 17 carcasses (11 wood and 6 boreal chorus frog tadpoles) were collected for detailed examination, 9 wood frog and 27 boreal chorus frog tadpoles were sampled and released, and 1 wood frog and 8 boreal chorus frog tadpole carcasses were sampled and discarded (see Table 1). From Site B $\left(60.034389^{\circ} \mathrm{N}, 113.12658^{\circ} \mathrm{W}\right)$, which is located $36 \mathrm{~km}$ west of Site A, 1 wood frog tadpole carcass was collected for detailed examination, and 12 wood frog and 30 boreal chorus frog tadpoles were sampled and released. Additionally, 30 Canadian toad Bufo (Anaxyrus) hemiophrys tadpoles, a species not found at site A during the outbreaks, were sampled and released from Site B (see Table 1). Gosner stage (Gosner 1960) and presence or absence of gross lesions (skin petechiae) were recorded for all tadpoles.

Both sites were sampled from mid-afternoon to early evening, with abiotic factors recorded around 18:00 $\mathrm{h}$ for Site A and 18:30 h for Site B. Abiotic factors (water temperature, conductivity, salinity and $\mathrm{pH}$ ) were recorded at each site using a YSI 556MPS field meter. Aseptic techniques and field hygiene protocols (Schock et al. 2010, Forzán \& Wood 2013) were used throughout the study to prevent crosscontamination of samples and accidental spread of pathogens among wetlands.

Tail clips, collected from all live and dead tadpoles, were immediately stored in $95 \%$ ethanol in the field and then stored at $-20^{\circ} \mathrm{C}$ until they were processed for PCR testing. Additional tissues, taken by sectioning the body of the tadpole longitudinally, were collected from 15 of the freshly dead tadpoles collected from Site A and from the single dead tadpole taken from Site B and stored frozen at $-20^{\circ} \mathrm{C}$. The remainder or whole body of each dead tadpole was then immediately fixed in $10 \%$ buffered formalin. The fixed tissues were shipped to the Cornell Wildlife Health Lab where they were processed for routine histopathological examination (hematoxylin and eosin staining, H\&E), followed by IHC staining for ranavirus. Briefly, IHC staining was performed using a polyclonal rabbit antibody against another member of the Ranavirus genus, epizootic haematopoietic necrosis virus (EHNV; Reddacliff \& Whittington 1996). Anti-EHNV antibodies are known to crossreact with other viruses in the genus (Ariel et al. 2010). A Leica BOND-MAX automated staining system (Leica Microsystems) ran a previously validated 
protocol for affinity purified rabbit anti-EHNV (lot no. M708, OIE Reference Laboratory for EHN Virus, University of Sydney) IHC staining (Maclaine et al. 2019). An ISH probe (ACDBio RNAscope Probe-VFV3-orf90R, catalog no. 439991, GenBank accession no. KF646249.1) was used to compare and confirm the IHC staining on a subset of 3 wood frog and 1 boreal chorus frog tadpoles. The protocol followed general manufacturer's specifications (Advanced Cell Diagnostics) (Maclaine et al. 2019). Negative controls for the IHC and ISH stains consisted of tissues from a boreal chorus frog tadpole that tested negative for ranavirus by PCR.

Tail clips were tested individually for the presence of ranavirus using quantitative PCR (qPCR; Leung et al. 2017). DNA was extracted using Qiagen DNEasy ${ }^{\circledR}$ Blood and Tissue kits according to the manufacturer's specifications.

We used a Synergy H1 Hybrid Multi-Mode Reader (BioTek) and the Quant-iT TM dsDNA BR Assay Kit for quantification of genomic DNA (Invitrogen). We used an Mx3005P qPCR System (Agilent Technologies) for qPCR. The cycle threshold $\left(C_{t}\right)$ was established for each 96-well plate by developing a standard curve with precise fit $\left(R^{2}>0.95\right)$ using a dilution series of a sample with a known quantity of frog virus 3 (FV3; $4.7 \times 10^{5}$ to $4.7 \times 10^{2}$ ). A no-template control (PCRgrade sterile water) was also run with each plate. Each reaction well contained $250 \mathrm{ng}$ of template DNA, $10 \mu \mathrm{l}$ TaqMan Universal PCR Master Mix 2X (Thermo Fisher Scientific), $1 \mu \mathrm{l}$ forward primer MCPRV_F (5'-GTC CTT TAA CAC GGC ATA CCT$\left.3^{\prime}\right)(10 \mu \mathrm{M}), 1 \mu \mathrm{l}$ reverse primer MCPRV_R $\left(5^{\prime}\right.$-ATC GCT GGT GTT GCC TAT C-3') $(10 \mu \mathrm{M})$, and $0.05 \mu \mathrm{l}$ TaqMan probe MCP_NFQ (5'-TTA TAG TAG CCT RTG CGC TTG GCC-3') (100 $\mu \mathrm{M})$. We added the correct amount of PCR-grade water to achieve the final reaction volume of $20 \mu$ l. Each sample was run in duplicate reactions. Samples were scored as positive if both reactions showed a clear amplification (i.e. surpassed the $C_{\mathrm{t}}$ ). If only one of the 2 runs showed amplification, a third run was conducted to confirm or dismiss the previous positive result. The FV3 stock was grown and provided by Craig Brunetti, Trent University, Ontario, Canada, from a multi-passage isolate going back to the 1965 FV3 isolated from a northern leopard frog Rana pipiens (Granoff et al. 1966).

\section{RESULTS}

All 18 tadpoles (12 wood and 6 boreal chorus frogs) collected for post-mortem examination showed gross lesions consistent with ranavirosis, i.e. petechial hemorrhages in the skin of the abdomen, tail base and developing hind limbs (Forzán \& Wood 2013) (Table 1). All 18 tadpoles had histologic lesions characteristic of fatal ranavirus infection (Miller et al. 2015, Forzán 2017) and corresponding positive IHC staining with anti-EHNV (ranavirus) antibody. The most common histopathologic lesion present was necrosis of the skin, oral mucosa (Fig. 2), renal tubular epithelium, renal hematopoietic tissue (Fig. 3), and branchial epithelium (Fig. 4). When budding limbs were present, skeletal and connective tissues were often undergoing multifocal to coalescing necrosis and were intensely positive with IHC staining, even in areas where no obvious necrosis could be observed (Fig. 4). Necrosis of the liver and pancreas was rare and mild, with occasional cellular debris, suggesting inflammation. Inclusion bodies in the liver were only definitively present in 2 tadpoles (Fig. 3H). Gastrointestinal and thymic necrosis were rarer and milder still, but there was common IHC

Table 1. Number of wood frog Rana sylvatica, boreal chorus frog Pseudacris maculata and Canadian toad Bufo (Anaxyrus) hemiophrys tadpoles sampled in 2017 from 2 wetlands (Sita A on June 20; Site B on June 26) in the Northwest Territories, Canada, during an outbreak of mortality due to ranavirosis. All tadpoles found were sampled (tail-clipped) for qPCR testing for Ranavirus sp. DNA. Freshly dead tadpoles were then collected for full postmortem examination, including histopathology, immunohistochemistry (IHC) and in situ hybridization (ISH). Presence of gross and histologic lesions, and positive (+) staining with IHC or ISH are included. Percentage of positive qPCR tests in the total number of tadpoles sampled is reported in parentheses. Histopathology and IHC were performed in all freshly dead carcasses collected; ISH was performed only in a subset of tadpoles found dead and examined histologically from Site A

\begin{tabular}{|c|c|c|c|c|c|c|c|c|c|c|c|c|c|c|c|c|}
\hline \multirow{2}{*}{$\begin{array}{l}\text { Location } \\
\text { (date) }\end{array}$} & \multirow[t]{2}{*}{ Found } & \multirow[b]{2}{*}{$\mathrm{n}$} & \multirow[b]{2}{*}{$\begin{array}{l}\text { Gross } \\
\text { lesions }\end{array}$} & \multicolumn{4}{|c|}{ Wood frog } & \multirow[b]{2}{*}{$\mathrm{n}$} & \multirow[b]{2}{*}{$\begin{array}{c}\text { Gross } \\
\text { lesions }\end{array}$} & \multicolumn{2}{|c|}{ Boreal chorus frog } & \multirow[b]{2}{*}{$\begin{array}{c}\mathrm{IHC} \\
(+)\end{array}$} & \multirow[b]{2}{*}{$\begin{array}{c}\text { ISH } \\
(+)\end{array}$} & \multicolumn{3}{|c|}{ — Canadian toad - } \\
\hline & & & & qPCR (+) & $\begin{array}{c}\text { Histologic } \\
\text { lesions }\end{array}$ & $\begin{array}{c}\mathrm{IHC} \\
(+)\end{array}$ & $\begin{array}{c}\text { ISH } \\
(+)\end{array}$ & & & qPCR (+) & $\begin{array}{l}\text { Histologic } \\
\text { lesions }\end{array}$ & & & $\mathrm{n}$ & $\begin{array}{l}\text { Gross } \\
\text { lesions }\end{array}$ & qPCR (+) \\
\hline \multirow[t]{2}{*}{ Site A } & Alive & 9 & 9 & $5(56 \%)$ & - & - & - & 27 & 8 & $25(93 \%)$ & - & - & - & 0 & - & - \\
\hline & Dead & 12 & 12 & $12(100 \%)$ & $11 / 11$ & $11 / 11$ & $2 / 2$ & 14 & 14 & $14(100 \%)$ & $6 / 6$ & $6 / 6$ & $1 / 1$ & 0 & - & - \\
\hline \multirow[t]{2}{*}{ Site B } & Alive & 12 & 4 & $12(100 \%)$ & - & - & - & 30 & 12 & $30(100 \%)$ & - & - & - & 30 & 1 & $10(33 \%)$ \\
\hline & Dead & 1 & 1 & $1(100 \%)$ & $1 / 1$ & $1 / 1$ & - & 0 & - & - & - & - & - & 0 & - & - \\
\hline
\end{tabular}




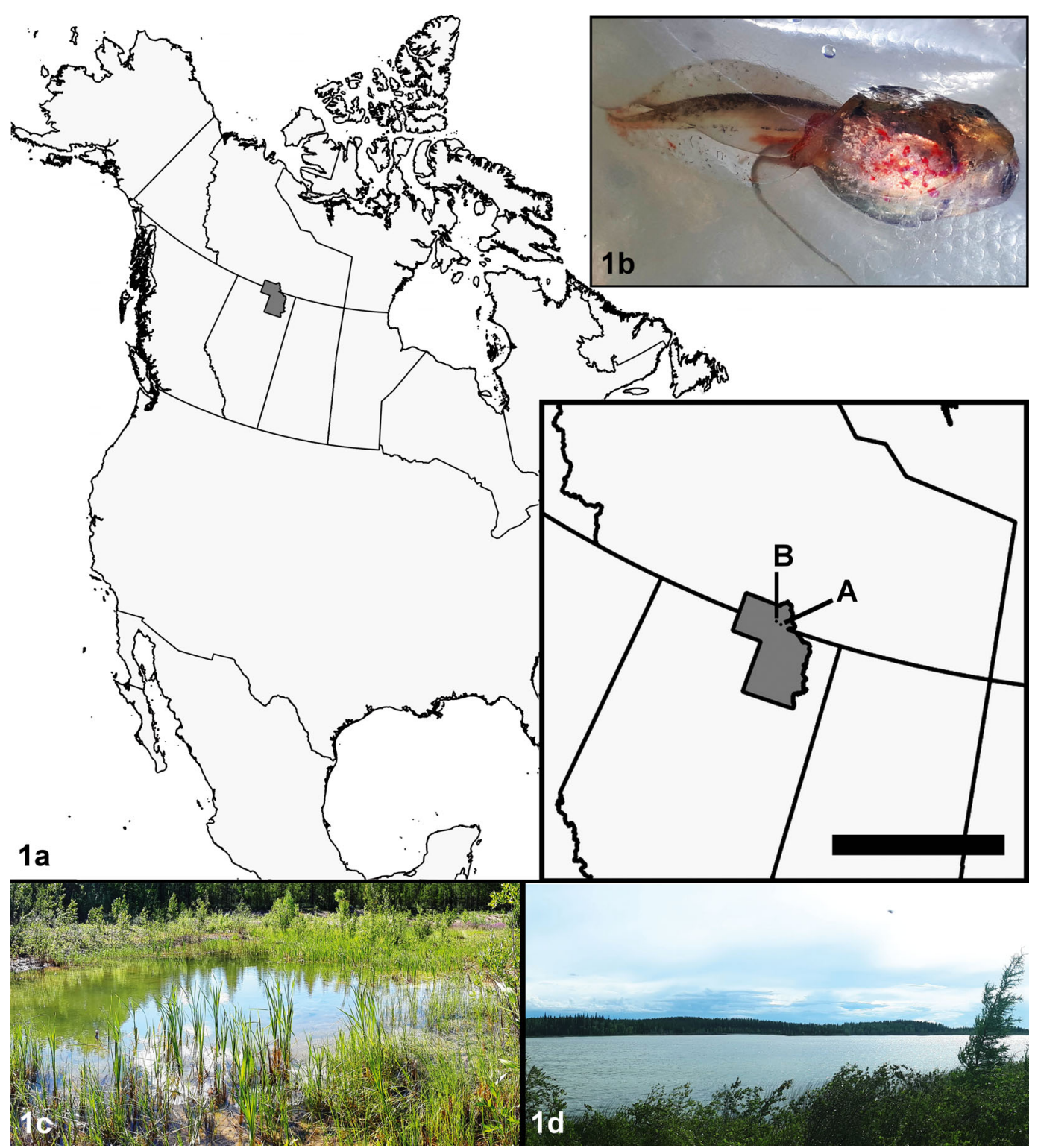

Fig. 1. (a and inset) Map of North America illustrating the approximate location of the outbreaks of ranavirosis in wood frog Rana sylvatica and boreal chorus frog Pseudacris maculata tadpoles within Wood Buffalo National Park on the border between Alberta and the Northwest Territories, Canada (grey shaded area; scale bar $=500 \mathrm{~km}$ ). (b) Wood frog tadpole with characteristic petechial hemorrhage in the ventral skin. $(c, d)$ Landscape of the outbreak locations (c: Site A; d: Site B)

staining in the mesothelium, thymic medulla and, occasionally, brain. The ISH staining performed in 2 wood frog and 1 boreal chorus frog tadpoles matched both the histopathologic lesions and IHC staining (Fig. 4). A ranavirus-negative wood frog tadpole confirmed the reliability of the stains: minimal background and non-specific staining was present with IHC and absolutely no staining with ISH (Fig. 4).

Additional findings, considered incidental, included degeneration and necrosis of the tail muscles (likely associated with metamorphic changes and not with ranavirosis), the presence of trematode metacercaria in the kidney, and, less frequently, the coelomic cavity of several tadpoles (Fig. 3). Tail muscle necrosis was present in tadpoles of both species, while metarcercaria were found only in wood frog tadpoles.

At the time of the outbreaks, tadpole development was at Gosner stages 33-37 at Site A and Gosner stages $36-41$ at Site B. Dead and moribund tadpoles with signs consistent with ranavirosis ranged from stage 33 to 37 at Site $A_{i}$ the single dead tadpole at Site B was stage 41 . 


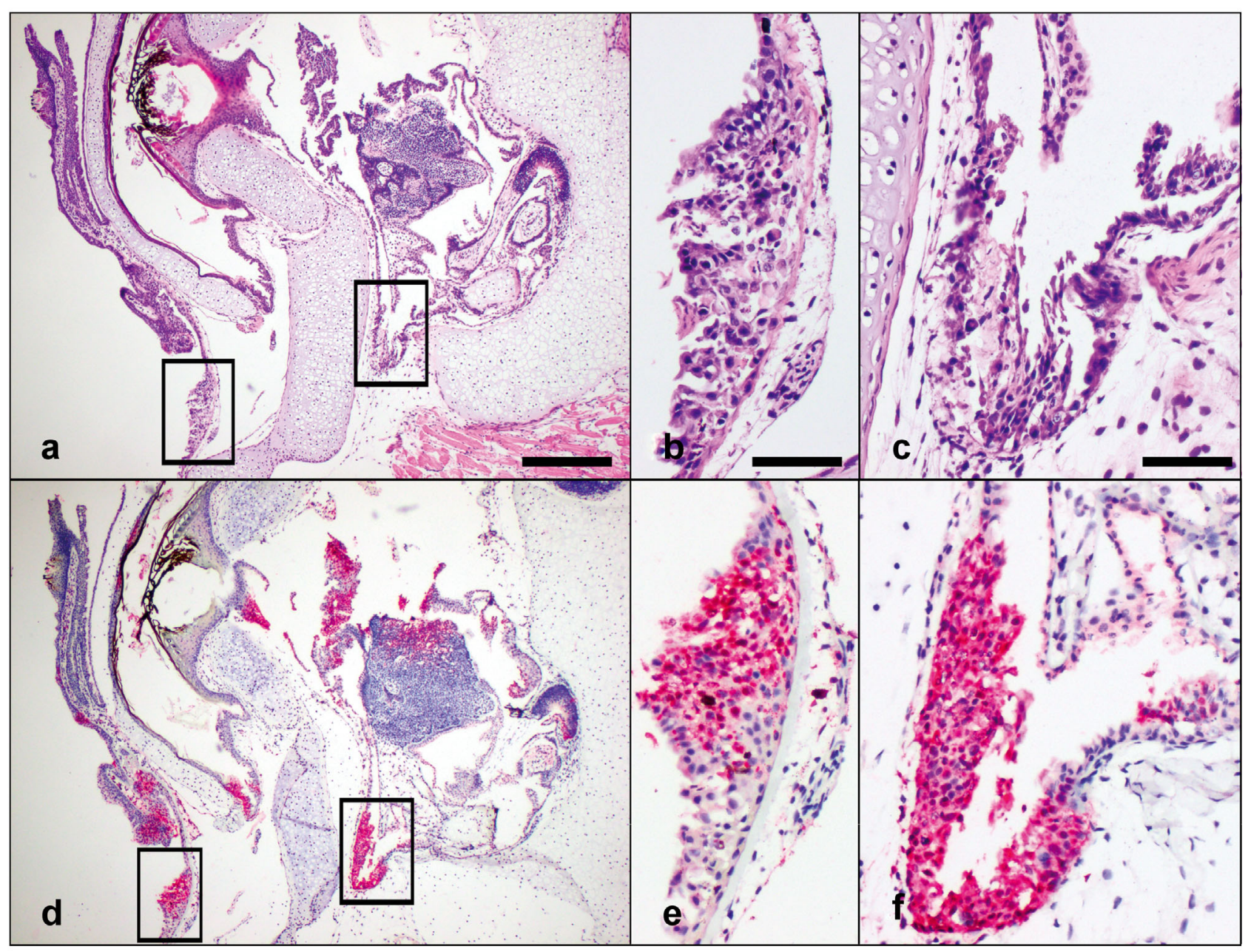

Fig. 2. Rostral portion of a wood frog Rana sylvatica tadpole in tangential section. $(\mathrm{a}-\mathrm{c})$ Multiple foci of epidermal (lower left square, (b) and oral mucosal (upper right square, (c) necrosis with stain. (d-f) Immunohistochemical (red) staining for Ranavirus sp. (anti-EHNV antibody) in epidermal and mucosal tissue is highly positive in foci of necrosis. Scale bars $=(\mathrm{a}, \mathrm{d})$ $400 \mu \mathrm{m},(\mathrm{b}, \mathrm{c}, \mathrm{e}, \mathrm{f}) 100 \mu \mathrm{m}$

All tadpoles found dead, including the 18 collected for post-mortem examination, had lesions consistent with ranavirosis and tested positive for ranavirus by qPCR. In tadpoles with mild or no signs of disease that were tail-clipped and released, qPCR results varied. At Site A, $56 \%$ (5/9) of wood frogs and $93 \%$ $(25 / 27)$ of boreal chorus frogs were positive for ranavirus DNA. At Site B, 100\% of tadpoles from both frog species were positive (12 wood frogs, 30 boreal chorus frogs), while only $33 \%(10 / 30)$ of Canadian toad tadpoles were positive.

With respect to abiotic factors, at Site A, water temperature was $22^{\circ} \mathrm{C}$, pH 7.97, conductivity $244 \mu \mathrm{S}$ $\mathrm{cm}^{-1}$ and salinity $0.12 \mathrm{ppt}$. At Site B, water temperature was $23.5^{\circ} \mathrm{C}, \mathrm{pH} 7.7$, conductivity $2559 \mu \mathrm{S} \mathrm{cm}{ }^{-1}$ and salinity $1.36 \%$.

\section{DISCUSSION}

We report fatal ranavirosis diagnosed in both wood and boreal chorus frog tadpoles. Our diagnosis was based on the molecular detection of ranavirus DNA combined with the presence of characteristic histological lesions along with ranavirus virions detected by IHC and, in a subset of tadpoles, by ISH. IHC and ISH were successfully used in both wood and chorus frog tadpoles and confirmed the positive PCR results. All tadpoles found dead or moribund yielded positive qPCR results from tail clips, whereas tail clips from tadpoles with mild or absent lesions (i.e. skin hemorrhages) were not always positive. Negative PCR results likely correspond to individuals that were not viremic at the time of sampling, as has been previ- 


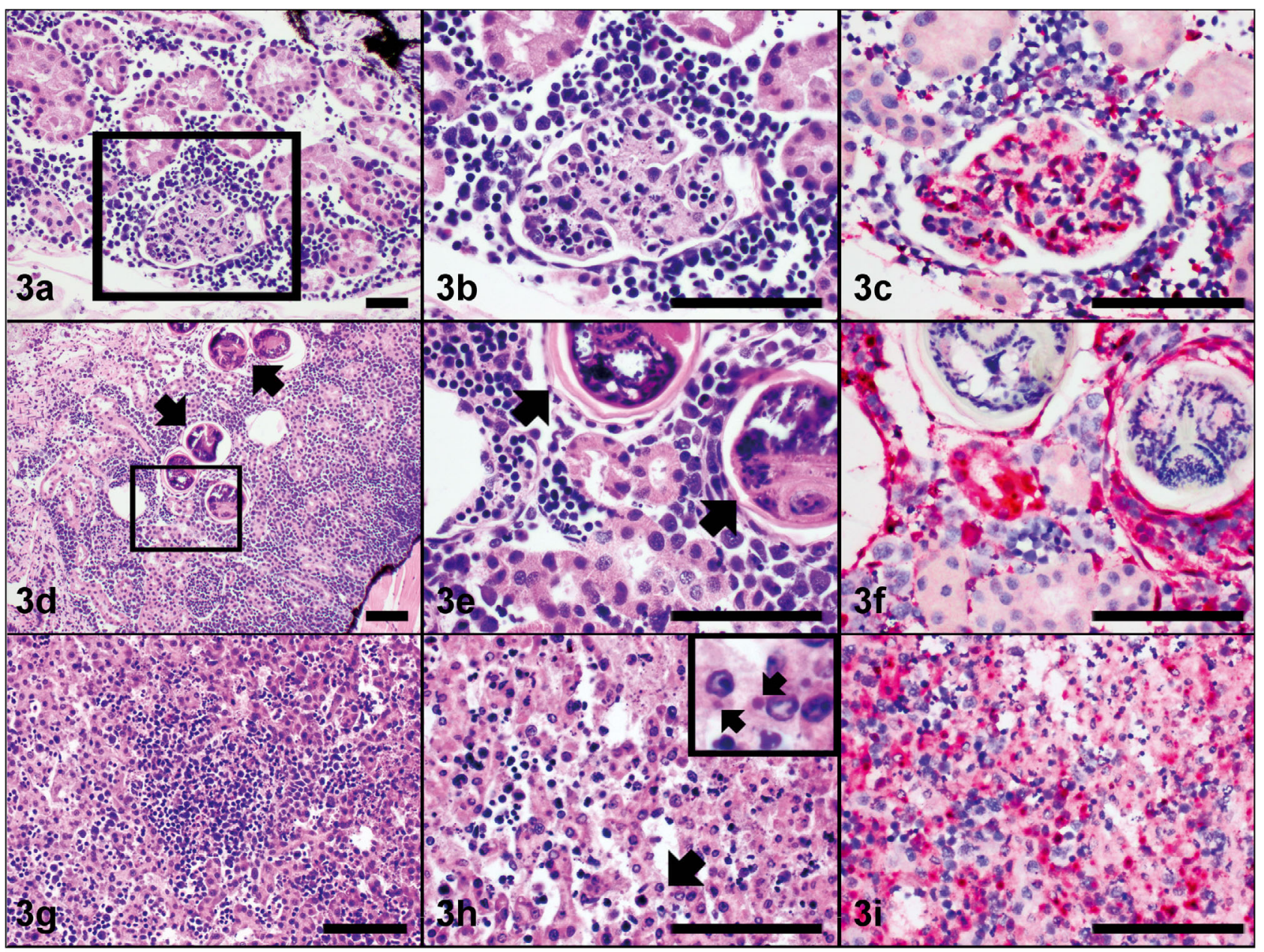

Fig. 3. (a-f) Kidney and (g-i) liver from wood frog Rana sylvatica tadpole stained with H\&E (a,b,d,e,g,h) and immunohistochemical staining with anti-EHNV antibody $(\mathrm{c}, \mathrm{f}, \mathrm{i})$. Foci of $(\mathrm{a}-\mathrm{c})$ renal glomerular, $(\mathrm{d}-\mathrm{f})$ tubular and (a-f) hematopoietic necrosis, (g-i) hepatocellular necrosis and (h) intracytoplasmic inclusions (arrows and inset) stain positively (red) for Ranavirus sp. Larval trematodes (metacercaria, arrows) are present in the renal interstitium (incidental finding). Scale bars $=(\mathrm{a}, \mathrm{d}) 50 \mu \mathrm{m}$, $(\mathrm{b}, \mathrm{c}, \mathrm{e}-\mathrm{i}) 100 \mu \mathrm{m}$

ously proposed (Greer \& Collins 2007). This disparity highlights the need for the development of sensitive tools that could detect ranavirus infection in subclinical individuals or populations.

A survey of multi-species amphibian communities in Nebraska reported positive PCR signals for ranavirus in a few boreal chorus frogs, less than $1 \%$ of individuals sampled (Davis \& Kerby 2016). Because there were no gross lesions or mortalities associated with the positive PCR results, and no postmortem examination was performed, it is possible that this low level of prevalence reflected an early infection or environmental contamination. Our study is thus the first report of an outbreak of fatal ranavirosis in boreal chorus frog tadpoles, including the first description of gross and histological lesions in the species. The outbreak occurred at 2 separate sites in the Canadian boreal forest and also involved wood frog tadpoles. Few studies have reported live ranavirus-positive individuals in wild populations of hylids even though hylids often overlap with members of Ranidae that are known to be highly susceptible to infection (e.g. wood frogs; Lesbarrères et al. 2011). For example, Schock et al. (2010) did not detect PCR-positive boreal chorus frogs in the Northwest Territories, Canada, at sites where wood frogs tested positive, although this may be due to the potential reduced sensitivity of conventional PCR, which was used by Schock et al. (2010), relative to qPCR (Miller et al. 2015), which was used in the present study. It is notable that less than half of the Canadian toad tadpoles sampled in our study had positive 


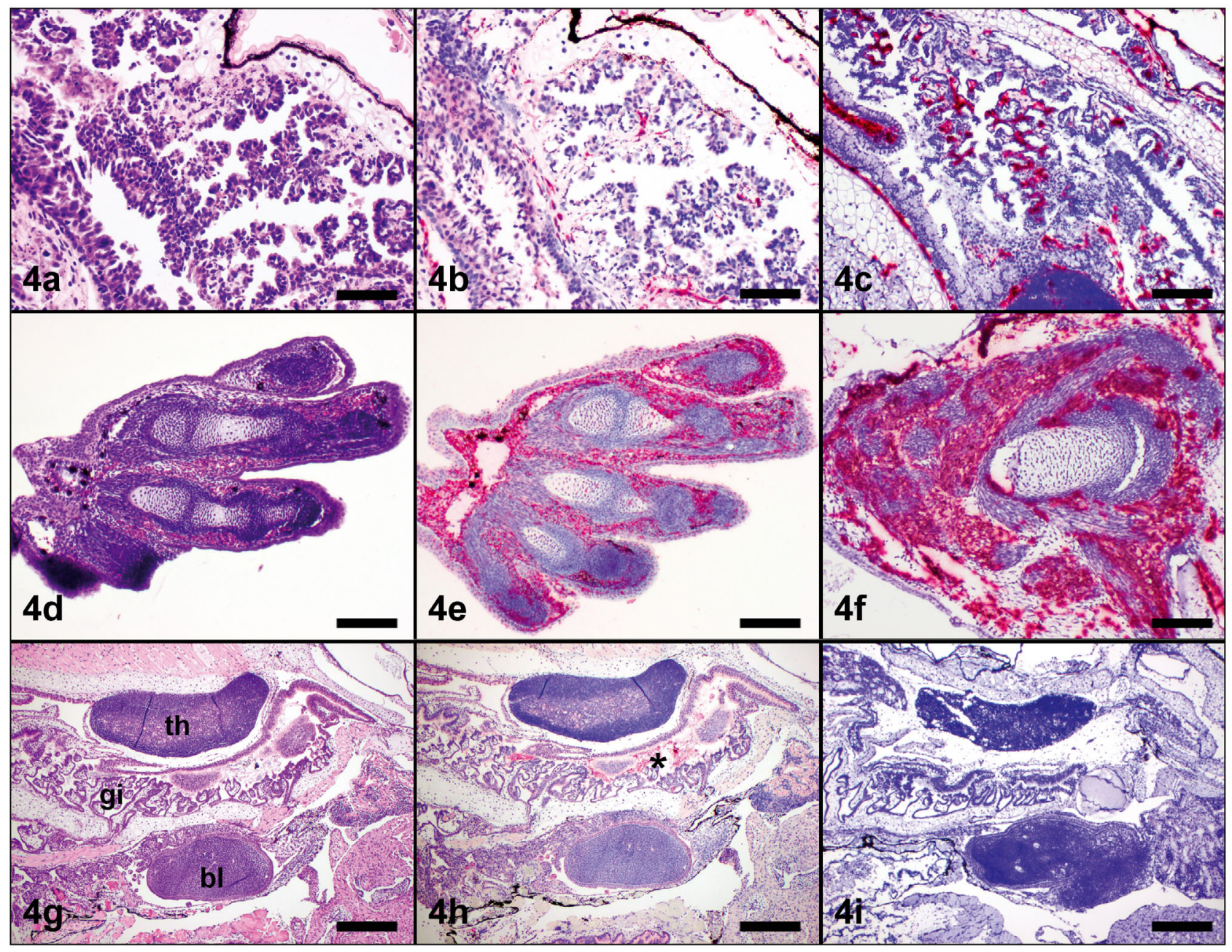

Fig. 4. Gills and budding limbs from (a-f) tadpoles with ranavirosis and ( $\mathrm{g}-\mathrm{i}$ ) an uninfected (negative) control. (a-c) Gills of a wood frog Rana sylvatica tadpole with branchial necrosis (a, H\&E) correspond with positive (b) immunohistochemical (IHC) and (c) in situ hybridization (ISH) staining (ACDBio FV3 probe) for Ranavirus sp. (red staining). (d-f) A budding hind limb of a boreal chorus frog Pseudacris maculata tadpole (d, H\&E), where rapidly growing connective and musculoskeletal tissues exhibit intense (e) IHC and (f) ISH staining for Ranavirus sp. (g-i) Gills (gi), a budding limb (bl), thymus (th) and other tissue from a wood frog tadpole with no evidence of ranavirosis serve as a negative control for the IHC and ISH. (h) Nonspecific IHC staining of amorphous material, including small ciliate protozoans (asterisk), is minimal and considered artifactual. (i) The ISH staining, being more specific, is completely absent in the ranavirus-negative tissues. Scale bars $=(\mathrm{a}-\mathrm{c})$ $100 \mu \mathrm{m},(\mathrm{d}-\mathrm{i}) 200 \mu \mathrm{m}$

qPCR results, even though most live wood and boreal chorus frog tadpoles sampled concurrently yielded positive qPCR results. This suggests that Canadian toads may be less susceptible to ranavirosis, although it is also possible that our study did not detect higher numbers of infected toads due to an offset in timing with respect to when this species may have succumbed to infection (e.g. mortalities occurred before or after our sampling took place). PCR sensitivity in non-lethal samples such as tail clips is reduced in non-viremic amphibians (Greer \& Collins 2007, Forzán \& Wood 2013), so the negative PCR results and lack of mortalities in Canadian toad tadpoles could indicate that sampling took place at either early or recovery stages of infection for that species.

Gross and histopathological lesions were similar in wood frog and boreal chorus frog tadpoles. As reported in wood frog adults (Forzán et al. 2017), ranavirosis in wood and boreal chorus frog tadpoles in this report manifested as a disseminated infection causing primarily massive necrosis of epithelium, endothelium and hematopoietic tissues. Positive IHC and ISH staining was detected in the brain of wood and boreal chorus frog tadpoles in our study. Detec- 
tion of ranaviral particles in the brain (besides those occasionally found in the endothelium of the choroid plexus) has been consistently absent in adult wood frogs with disseminated and fatal ranavirosis (Forzán et al. 2015, 2017). Our findings are consistent with what is reported in African clawed frog Xenopus laevis tadpoles, where the virus commonly transcends the blood-brain barrier into the neuropil in tadpoles but not in adults (Andino et al. 2016). Abundant and active replication of virus, as demonstrated by intense IHC and ISH staining, was detected in connective tissues, particularly those in the budding limbs.

Besides characterizing the lesions present in fatal ranavirosis in boreal chorus tadpoles, our study is the first to validate the use of IHC and ISH in detecting the pathogen and diagnosing the disease in this species. It is also, to our knowledge, the first published report of the use of ISH to detect ranavirus in Ranidae and Hylidae tadpoles. It must be noted that the antibody and probe we used for IHC and ISH, respectively, detect multiple species of ranavirus. The anti-EHNV antibody has been used successfully in experimental infections with at least 2 species of ranavirus with a very different geographical distribution: FV3 (Forzán et al. 2017) and Bohle iridovirus (Maclaine et al. 2019). The ISH probe, although labeled as 'FV3' by the manufacturer, detects FV3 (M. J. Forzán unpubl. data) as well as Bohle iridovirus (Maclaine et al. 2019) and common midwife toad virus (M. J. Forzán unpubl. data). The ISH probe is particularly useful for certain amphibian species, such as $X$. laevis and various plethodontid salamanders, where the routine protocol for IHC with the anti-EHNV antibody produces marked non-specific staining of the host tissues (M. J. Forzán unpubl. data). As both IHC antibody and ISH probe are specific only to the Ranavirus genus, identification of the species involved in this outbreak is beyond the scope of the present study.

Ranaviral preference for tissues usually undergoing active proliferation suggests that the virus thrives in fast-growing host cells and is an intriguing possible reason for mortalities occurring in synchrony with a specific stage of metamorphosis. If fatal ranavirosis is associated with rapid tissue growth, it may explain outbreaks occurring simultaneously across wide geographical areas (Brunner et al. 2015), as tadpoles of a particular species would likely grow at similar rates and thus develop disease at the same time. In our study, populations of wood and boreal chorus frogs, separated by almost $40 \mathrm{~km}$, suffered fatal ranavirosis outbreaks within a period of $10 \mathrm{~d}$ when tadpoles were at a similar metamorphic stage. Abiotic factors, such as temperature, have been suggested to trigger ranaviral outbreaks, given their influence on the amphibian immune system (Hoverman et al. 2012). However, our opportunistic sampling does not allow us to evaluate the possible link between temperature and ranavirosis emergence. Recently, developmental stage was found to be a strong driver in the occurrence of ranavirus outbreaks, at least in wood frog populations (Hall et al. 2018). Our observation of abundant replication of virus in tissues from structures closely tied to metamorphic stage (i.e. budding limbs) does support the link between developmental stage and disease emergence.

In conclusion, we report an outbreak of ranavirosis in wild anuran tadpoles, including the first confirmed case of fatal ranavirosis in boreal chorus frog, diagnosed through a combination of histopathological, histochemical (IHC and ISH) and molecular (qPCR) techniques. Abundant IHC and ISH staining in actively growing tissues supported a link between disease emergence and amphibian developmental stage. Ultimately, our findings demonstrate the need for multi-tool approaches to investigate mortality events if we are to reach definitive diagnoses and better understand ranavirus ecology and pathogenesis in wild amphibians.

Acknowledgements. Funding for this project was provided by the Ontario Trillium Foundation to J.B., and a National Science and Engineering Research Council of Canada grant to D.L. Parks Canada, Aurora College, and the Government of the Northwest Territories provided in-kind logistical support. We respectfully acknowledge that our fieldwork was conducted on Treaty 8 Territory. We also thank Melissa Fadden for her technical assistance with the in situ hybridization staining.

\section{LITERATURE CITED}

Andino FDJ, Jones L, Maggirwar SB, Robert J (2016) Frog Virus 3 dissemination in the brain of tadpoles, but not in adult Xenopus, involves blood brain barrier dysfunction. Sci Rep 6:22508

Ariel E, Holopainen R, Olesen NJ, Tapiovaara H (2010) Comparative study of ranavirus isolates from cod (Gadus morhua) and turbot (Psetta maxima) with reference to other ranaviruses. Arch Virol 155:1261-1271

Brunner JL, Storfer A, Gray MJ, Hoverman JT (2015) Ranavirus ecology and evolution: from epidemiology to extinction. In: Gray MJ, Chinchar VG (eds) Ranaviruses. Springer, Cham, p 71-104

Davis DR, Kerby JL (2016) First detection of ranavirus in amphibians from Nebraska, USA. Herpetol Rev 47:46-50

Forzán MJ, Wood J (2013) Low detection of ranavirus DNA in wild postmetamorphic green frogs, Rana (Lithobates) 
clamitans, despite previous or concurrent tadpole mortality. J Wildl Dis 49:879-886

Forzán MJ, Jones KM, Vanderstichel RV, Wood J and others (2015) Clinical signs, pathology and dose-dependent survival of adult wood frogs, Rana sylvatica, inoculated orally with frog virus 3 Ranavirus sp., Iridoviridae. J Gen Virol 96:1138-1149

Forzán MJ, Jones KM, Ariel E, Whittington RJ, Wood J, Markham RJF, Daoust PY (2017) Pathogenesis of frog virus 3 (Ranavirus, Iridoviridae) infection in wood frogs (Rana sylvatica). Vet Pathol 54:531-548

Gascon C, Collins JP, Moore RD, Church DR, McKay JE, Mendelson JR III (eds) (2007) Amphibian Conservation Action Plan. IUCN/SSC Amphibian Specialist Group, Gland

Gosner KL (1960) A simplified table for staging anuran embryos and larvae with notes on identification. Herpetologica 16:183-190

Granoff A, Came PE, Breeze DC (1966) Viruses and renal carcinoma of Rana pipiens: I. The isolation and properties of virus from normal and tumor tissues. Virology 29: 133-148

Greer AL, Collins JP (2007) Sensitivity of a diagnostic test for amphibian Ranavirus varies with sampling protocol. J Wildl Dis 43:525-532

Hall EM, Goldberg CS, Brunner JL, Crespi EJ (2018) Seasonal dynamics and potential drivers of ranavirus epidemics in wood frog populations. Oecologia 188: 1253-1262

Hoverman JT, Gray MJ, Miller DL, Haislip NA (2012) Widespread occurrence of ranavirus in pond-breeding amphibian populations. EcoHealth 9:36-48

Kriger KM, Ashton KJ, Hines HB, Hero JM (2007) On the biological relevance of a single Batrachochytrium den-

Editorial responsibility: Douglas Woodhams,

Boston, Massachusetts, USA drobatidis zoospore: a reply to Smith. Dis Aquat Org 73: $257-260$

KLesbarrères D, Balseiro A, Brunner J, Chinchar VG and others (2011) Ranavirus: past, present and future. Biol Lett 8 : 481-483

* Leung WT, Thomas-Walters L, Garner TW, Balloux F, Durrant C, Price SJ (2017) A quantitative-PCR based method to estimate ranavirus viral load following normalisation by reference to an ultraconserved vertebrate target. J Virol Methods 249:147-155

Maclaine A, Forzán MJ, Mashkour N, Scott J, Ariel E (2019) Pathogenesis of Bohle iridovirus, (genus Ranavirus) in experimentally infected juvenile eastern water dragons (Intellagama lesueurii lesueurii). Vet Pathol 56:465-475

*Maxie G (2016) Autopsy/necropsy, diagnosis/detection... what's in a word? J Vet Diagn Invest 28:87

* May RM (1988) Conservation and disease. Conserv Biol 2: 28-30

Miller DL, Pessier AP, Hick P, Whittington RJ (2015) Comparative pathology of ranaviruses and diagnostic techniques. In: Gray M, Chinchar V (eds) Ranaviruses. Springer, Cham, p 171-208

* Reddacliff LA, Whittington RJ (1996) Pathology of epizootic haematopoietic necrosis virus (EHNV) infection in rainbow trout (Oncorhynchus mykiss Walbaum) and redfin perch (Perca fluviatilis L). J Comp Pathol 115:103-115

* Schock DM, Ruthig GR, Collins JP, Kutz SJ and others (2010) Amphibian chytrid fungus and ranaviruses in the Northwest Territories, Canada. Dis Aquat Org 92:231-240

Wren S, Angulo A, Meredith H, Kielgast J, Dos Santos M, Bishop P (eds) (2015) Amphibian Conservation Action Plan. IUCN SSC Amphibian Specialist Group. www.amphibians.org/resources/library/acap/ (accessed 5 June 2019)

Submitted: December 13, 2018; Accepted: March 11, 2019 Proofs received from author(s): June 6, 2019 